\title{
Pinturas rupestres de la cueva de "La Graja". Caracterización de pigmentos y análisis digital de imágenes
}

\section{Rupestral paintings of the "La Graja" cave. Pigment characterization and digital image analysis}

\author{
A. PALOMO ${ }^{(*)}$, M.T. BLANCO-VARELA ${ }^{(*)}$, P. HERRERO $^{(*)}$, N. PRENDES ${ }^{(* *)}$
}

(*)Instituto de Ciencias de la Construcción Eduardo Torroja (CSIC),

Fecha de recepción: 11-III-03

Fecha de aceptación: 20-V-03

ESPAÑA

\section{RESUMEN}

La presente investigación forma parte de un estudio amplio desarrollado en torno a un conjunto de yacimientos arqueológicos localizados en la Comunidad Autónoma de Andalucia y que tenia como objetivo fundamental el conocimiento de dichos yacimientos dentro de los contextos geomorfológico, biológico y climático.

En este caso concreto se abordó el estudio relativo a los procesos de alteración de las pinturas rupestres que se encuentran en la cueva de "La Graja" (provincia de Jaen). Dichos procesos, se ha concluido que están relacionados principalmente con la alta disponibilidad de agua en su zona de ubicación.

La composición de las pinturas no es lo que usualmente se encuentra en otros abrigos estudiados con anterioridad, en donde predominan los óxidos de hierro. La presencia de óxidos de cobre, titanio y cerio indican un alejamiento de la tónica común que se da en las pinturas rupestres andaluzas.

\section{SUMMARY}

The present study is part of a wide-ranging research on a group of archaeological sites located in Andalucia (Spain) whose main aim was a better understanding of these sites within a geomorphological, biological and climatic context.

This specific investigation concerns the alteration processes affecting the rupestral paintings found in the cave of " $\mathrm{La}$ Graja". It has been concluded that such processes are related mainly to the high availability of water at the site's location.

The paint's composition diverges from that usually encountered in other, previously studied shelters, where iron oxides have been found to prevail. The presence of copper oxides, titanium and cerium represents a departure from the common findings in Andalusian rupestral paintings.
PALABRAS CLAVE: pinturas rupestres, pigmentos, caracterización, análisis de imágenes.

\section{INTRODUCCIÓN}

La cueva de «La Graja» está situada en el término municipal de Jimena (Jaén), aproximadamente a $1 \mathrm{~km}$ del núcleo urbano, en un farallón calizo que constituye una de las paredes del valle en que se ubica (ver Figura 1).
KEYWORDS: old paintings, pigments, characterisation, image analysis.

\section{INTRODUCTION}

The cave of "La Graja» is located in the township of Jimena (Jaén province), approximately $1 \mathrm{~km}$. from the town center, in a calcareous outcropping that forms one side of the valley in which it is located (see Figure 1). 


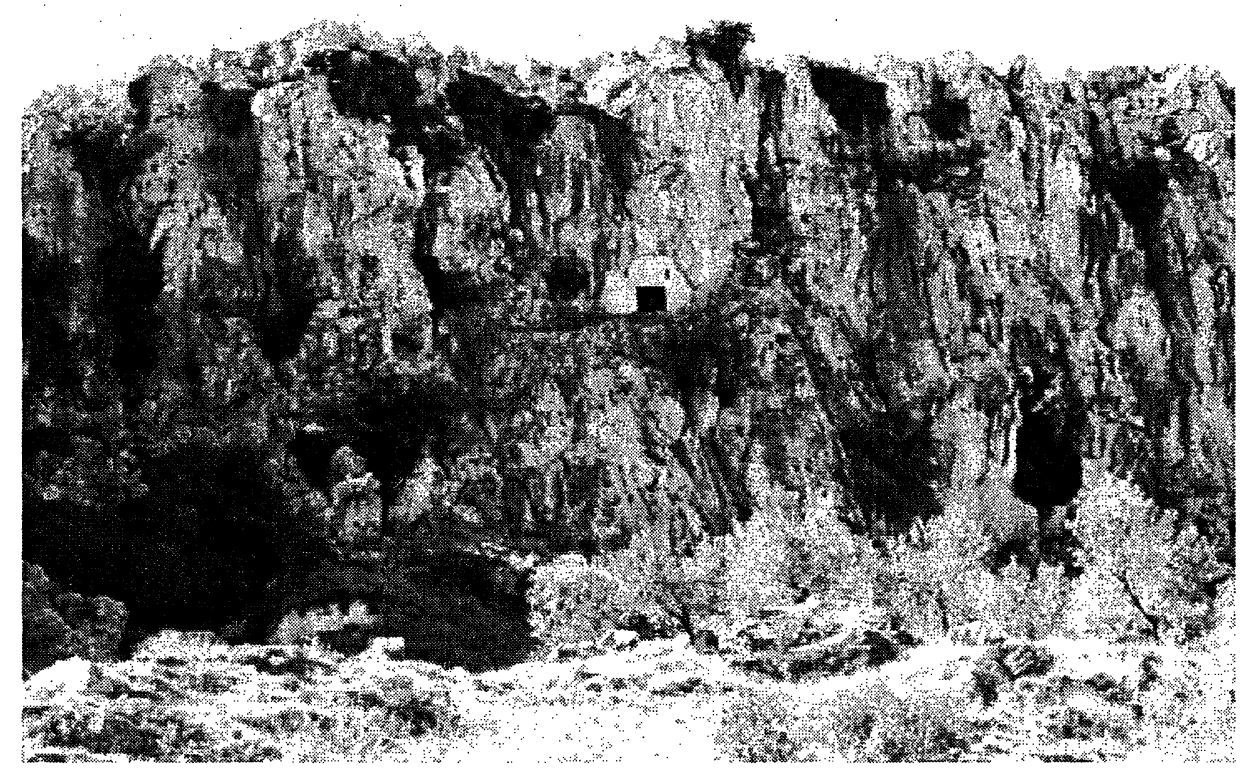

Figura 1.- En el centro de la fotografia se distingue con claridad la entrada artificial habilitada para el acceso a la cueva.

Figure 1.- In the middle of the picture clan clearly seen the artificial entrance made to accede to the cave.

El abrigo en sí mismo presenta dimensiones muy reducidas, con un cierre artificial que consiste en una puerta metálica y un muro adosado a las paredes. El cierre permite una correcta ventilación a través de la propia puerta y también de un respiradero situado en la parte superior.

Consta el abrigo de una estancia inicial $(5 \mathrm{~m}$ de ancho $\mathrm{x} 3 \mathrm{~m}$ de alto $\mathrm{x} 3 \mathrm{~m}$ de profundidad y una pequeña cavidad interior de unos $2 \mathrm{~m}$ de ancho y 1,5 $\mathrm{m}$ de largo). Además existe otra pequeña estancia en el interior, de menor tamaño y sin acceso.

En la parte alta y en lado izquierdo de la primera de las estancias mencionadas (la mas grande) se observa un conjunto de pinturas, aparentemente bien conservadas, con representaciones antropomorfas y de animales (ver Figuras 2 y 3). En la parte baja de la misma estancia, en una zona de fácil acceso, se encuentra otro conjunto de pinturas en un estado de deterioro alarmante.

Desde el punto de vista geológico, la roca soporte de las representaciones rupestres corresponde a calizas de algas y calcarenitas, con esporádicos y delgados niveles de margas blancas intercaladas. En general, se presentan masivas o bien en gruesos estratos de orden métrico. Se observan muy pocas estructuras de ordenamiento interno, salvo algunas laminaciones paralelas, si bien los estratos se agrupan en sets con estratificación cruzada planar de aproximadamente $1,5 \mathrm{~m}$ de potencia, que parecen relevarse lateralmente (barras calcareníticas).
The shelter itself is of very small dimensions, with an artificial closing that consists of a metallic door and a man-made wall abutting the cave walls. The closing permits proper ventilation through the door itself, as well as from a vent located in its upper portion.

The shelter consists of a first chamber $(5 \mathrm{~m}$ wide by $3 m$ high by $3 m$ deep) and a small interior hollow (about $2 \mathrm{~m}$. wide and $1.5 \mathrm{~m}$ long). There is also another room in the interior, smaller in size and with no access to the exterior:

The upper portion of the left side of the first chamber mentioned (the larger) bears a group of apparently wellconserved paintings with anthropomorphous and animal representations (see Figures 2 and 3). In the lower part of the same room, in an easily accessible area, is another group of paintings in an alarming state of deterioration.

From the geological point of view, the rocky substrate of the rupestral representations correspond to algae limestones and calcrete, with sporadic thin horizons of white loam insertions. In general, they occur as massifs or in thick strata. Very few structures of internal order are observed, except for some parallel laminations, though the strata are grouped together in sets with crossed planar stratification of approximately $1.5 \mathrm{~m}$ thickness that seem to raise laterally (calcrete beds). 


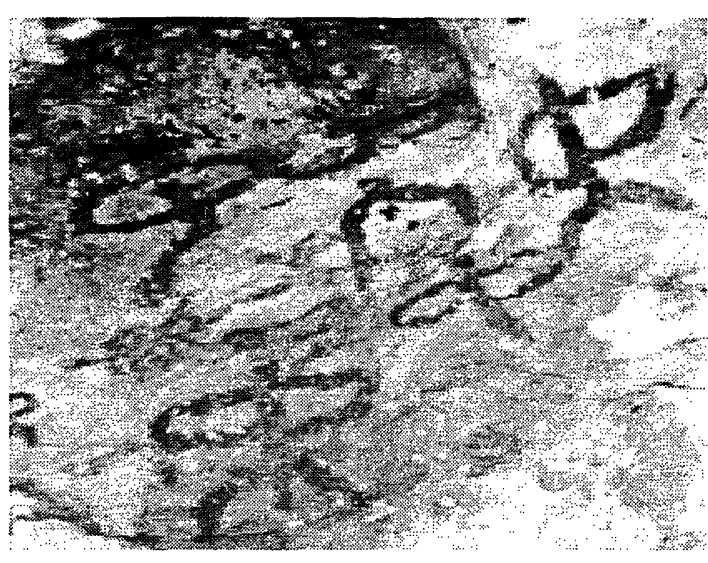

Figura 2.- Grupo de antropomorfos y animales.

Figure 2.- Group of antropomorphic and animals.

En la zona visitada, únicamente se han observado dos puntos de goteo de escaso caudal, que dan lugar al crecimiento de dos estalactitas muy pequeñas, $y$ sus correspondientes costras estalagmíticas en el suelo

\section{OBJETIVOS}

El objetivo fundamental planteado en el presente trabajo se centró en la investigación en torno a la naturaleza de los pigmentos empleados en las pinturas rupestres encontradas en la cueva de «La Graja». Asimismo, como objetivo complementario se planteó la posibilidad de cuantificar por medio del tratamiento digital de imágenes el porcentaje de superficie deteriorada de algunas representaciones concretas (antropomorfos y otras figuras) presentes en las paredes de la cueva.

\section{DESARROLLO EXPERIMENTALY RESULTADOS}

En las Figuras 2 y 3 se ofrece una perspectiva de las zonas y los elementos pictóricos concretos seleccionados en la etapa de muestreo. La denominación establecida en el texto para las cuatro muestras es G1, G2, G3 y G4

A continuación se describe la metodología de trabajo empleada en el estudio de cada uno de los pigmentos muestreados en las pinturas rupestres de la cueva de «La Graja»; metodología idéntica en todos los casos

MUESTRA G1. Tomada de una representación antropomórfica de tonalidad parda.

En la Figura 4 se presenta una imagen de la muestra G1 tal y como se observa con la lupa a 90 aumentos. Se identifica en dicha fotografía un soporte de color blanco (perteneciente al substrato pétreo) impregnado de una delgada capa de color pardo oscuro correspondiente al pigmento objeto de estudio.

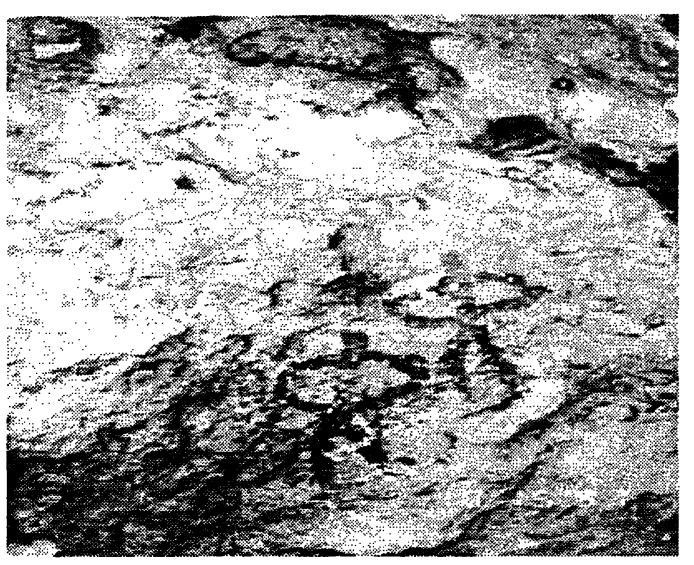

Figura 3.- Pareja antropomorfica.

Figure 3.- Antropomorphic couple.

In the inspected area, only two points of minor leakage have been observed. These give rise to the growth of two very small stalactites and their corresponding stalagmite crusts on the floor.

\section{OBJECTIVES}

The fundamental objective pursued in the present study centered around determining the nature of the pigments used in the rupestral paintings found in the "La Graja" cave. Moreover, as a secondary objective, we planned to assess the application of digital imaging techniques to quantify the percentage of surface deterioration in some specific drawings present on the cave walls (anthropomorphic and other figures).

\section{EXPERIMENTAL METHODS AND RESULTS}

Figures 2 and 3 show a panorama of the site and the specific pictorial elements selected during the sampling stage. For the purposes of description in the present paper, the four samples collected have been designed as $G 1, G 2, G 3$ and $G 4$.

The following describes the methodology adopted, identical in all cases, in studying the pigments sampled from the rupestral paintings of the cave of «La Graja».

\section{SAMPLE G1. Taken from a grayish-brown anthropomorphic figure.}

Figure 4 presents an image of sample G1, exactly as it appears magnified 90 times with a lens. The photograph clearly reveals the white-colored support (belonging to the rock substrate) impregnated with a thin layer of dark grayish-brown color corresponding to the pigment to be analyzed. 


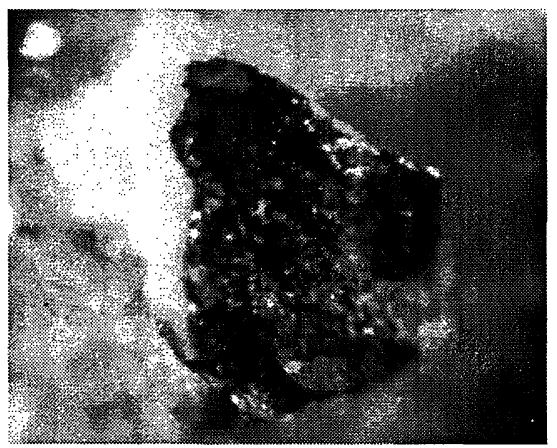

Figura 4.- Muestra Gl (x90).

Figure 4.- Sample GI (x90).

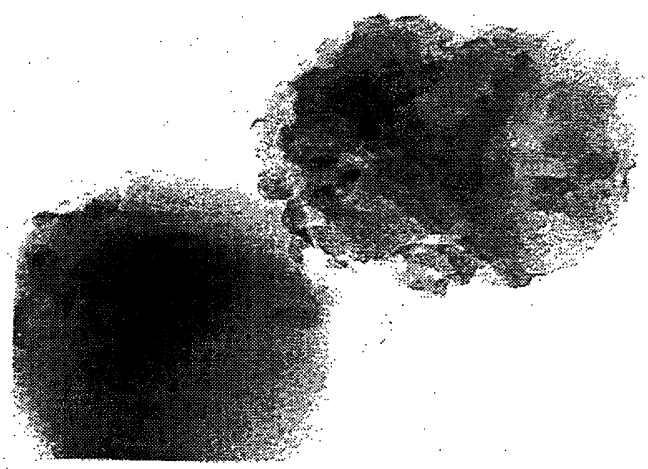

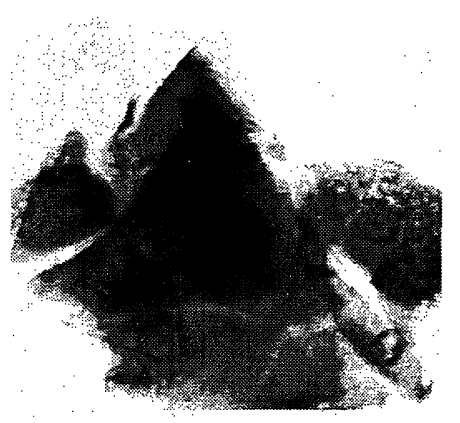

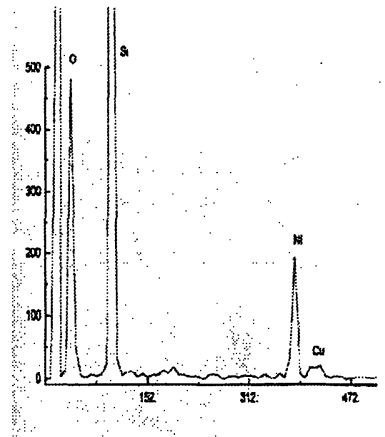

Figura 5.- Imagen TEM y microanálisis de G1.

Figure 5.- TEM image and microanalysis of GI.

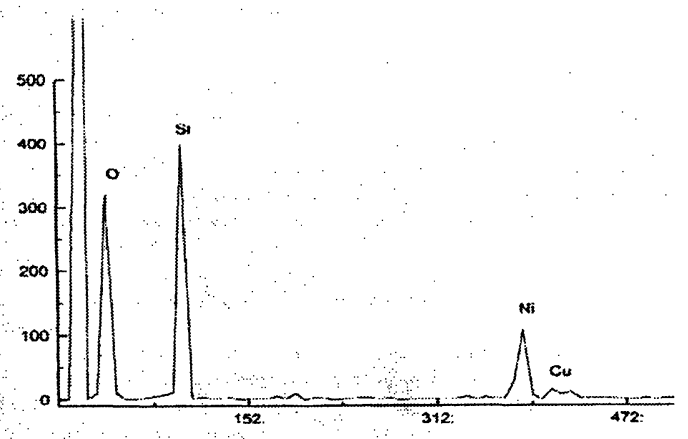

Figura 6.- Imagen TEM y microanálisis de la muestra G1.

Figure 6. - TEM image and microanalysis of sample G1.

Para determinar la composición elemental del pigmento se examinó la muestra a través del microscopio electrónico de transmisión (TEM) y se analizó por medio del microanálisis.

La micrografía que se presenta en la Figura 5 corresponde a un tipo de partícula que se encuentra con frecuencia en esta muestra y que según se desprende de su análisis elemental, está compuesta básicamente de sílice. Se interpreta que dicho material procede del substrato pétreo en el que se asienta la pintura.

El material que se presenta en la Figura 6, independientemente de mostrar una morfología de cristal diferente a la observada en la figura anterior, presenta un análisis en el que se identifican con mayor claridad las radiaciones $\mathrm{K} \alpha$ y $\mathrm{K} \beta$ pertenecientes al cobre. También se detectan en cantidades variables otros elementos tales como el silicio, el calcio, el fósforo y el níquel. La presencia de dichos elementos se considera ajena a la propia naturaleza de las pinturas y se puede justificar en función de su pertenencia al soporte pétreo en el que se encuentra la pintura. El caso del fósforo podría tener un origen orgánico y ser una consecuencia de la actividad biológica (microorganismos, aves) que se desarrolla en la cueva. Finalmente y en lo que al níquel respecta, su presencia se debe a la rejilla en la que se coloca la muestra en el interior del microscopio, para su análisis.
In order to determine the pigment's elemental composition, the sample was examined with a transmission electron microscope (TEM) and subjected to microanalysis.

The micrograph shown in Figure 5 corresponds to a type of particle encountered frequently in this sample. From the elemental analysis it results to be made up essentially of silica, and has thus been interpreted as originating in the rocky substrate underlying the paint.

The material shown in Figure 6, apart from exhibiting a different crystal morphology from that observed in the previous figure, yields analysis results which clearly identify the $K \alpha$ and $K \beta$ radiations as belonging to copper. Varying amounts of other elements are also detectable, such as silicon, calcium, phosphorus and nickel. The presence of such elements is to be considered alien to the very nature of the paints and may be accounted for by attributing them to the rocky support on which the painting lies. With regard to the phosphorus, this may have organic origins and stem from biological activities carried out by, for example, micro-organisms and birds within in the cave. Finally, regarding the nickel, its presence is clearly' due to the sample holder when it is placed in the microscope for analysis. 
La variabilidad detectada en las intensidades de las radiaciones características de cada elemento es un factor estrictamente estadístico que depende del espacio puntual analizado y de la cantidad de cada elemento presente en dicho espacio. Este es el motivo por el cual cada muestra fue analizada en un número de puntos no inferior a seis.

En definitiva, se desprende de los datos obtenidos por medio del TEM/EDX que el único elemento cromóforo presente en la muestra es el cobre y, consecuentemente, se deduce que la pintura utilizada para representar el antropomorfo del que se extrajo la muestra G1 fue preparada utilizando algún mineral de cobre. Minerales típicos del cobre son los sulfuros, óxidos y carbonatos tales como la Cuprita $\left(\mathrm{Cu}_{2} \mathrm{O}\right)$, Calcopirita $\left(\mathrm{CuFeS}_{2}\right)$, Malaquita $\left(\mathrm{Cu}_{2} \mathrm{CO}_{3}(\mathrm{OH})_{2}\right)$, etc.

La no detección de cantidades significativas de azufre induce a pensar que el mineral objeto de estudio es un óxido, ya que los carbonatos de cobre suelen dar coloraciones verdes y azuladas (1), lo cual los excluye categóricamente como pigmentos presentes en la muestra G1. En lo que a los óxidos respecta, el cobre tan sólo forma el óxido cuproso, de color rojo, y el óxido cúprico de color pardo oscuro. Los compuestos cuprosos, en términos generales, son fácilmente oxidables y en condiciones atmosféricas normales se oxidan a compuestos cúpricos. Todo, pues, parece indicar que la coloración del antropomorfo del que se extrajo la muestra G1 es debida a la presencia de óxido cúprico.

MUESTRA G2. Tomada de un antropomorfo de tonalidad parda pero mas clara que la muestra G1.

En la Figura 7 se presenta una imagen de la muestra G2, obtenida por medio del microscopio estereoscópico y aumentada 45 veces respecto de su tamaño original. De manera similar a como ocurría con la muestra G1, el pigmento, de un color pardo rojizo no demasiado intenso, se encuentra impregnando la superficie de un material pétreo de color blanquecino y en ocasiones, translúcido.

Los resultados del análisis elemental (obtenidos por medio del EDX) de la muestra G2 indican una mayor complejidad composicional de ésta cuando se compara con la composición deducida en la muestra G1.

En la Figura 8 se muestra la imagen TEM correspondiente a un par de partículas del pigmento en cuestión. Y en la Figura 9 sendos espectros elementales de dos análisis de la muestra G2. La presencia de elementos tales como el carbono, silicio, calcio, etc. se justifican nuevamente en base a que éstos pueden formar parte tanto de la piedra soporte como del material de relleno sobre el que se incorpora el pigmento. También cabe la posibilidad de que el pigmento (pardo rojizo) incluya, en este caso, más de un compuesto químico. Así, por ejemplo, se detecta la
The variability detected in the intensities of each element's characteristic radiation is a strictly statistical factor which depends upon the specific point analyzed and the quantity of each element present at that point. This is the reason that each sample was analyzed in no less than six different places.

In summary, from the data obtained by means of the TEM/ $E D X$, it can be concluded that the only chromophore element present in the sample is copper. It can therefore be deduced that the paint used to make the anthropomorphous illustration from which sample Gl was extracted was prepared using some mineral of copper. Typical copper minerals are the sulfides, oxides and carbonates such as Cuprite $\left(\mathrm{Cu}_{2} \mathrm{O}\right)$, Chalcopyrite $(\mathrm{CuFeS})$, Malachite $\left(\mathrm{Cu}_{2} \mathrm{CO}_{3}(\mathrm{OH})_{2}\right)$, etc.

The lack of significant detected amounts of sulfur leads us to believe that the mineral under study is an oxide because copper carbonates usually yield green and blue colors (1), a fact which categorically excludes them as pigments present in sample G1. Regarding the oxides, copper by itselfforms cuprous oxide, which is red in color, and the dark gray-brown cupric oxide. In general terms, cuprous compounds are easily oxidized and under normal atmospheric conditions become oxidized to cupric compounds. Thus, all told, the evidence seems to indicate that the coloring of the anthropomorphous drawing from which sample G1 was extracted is due to the presence of cupric oxide.

\section{SAMPLE G2. Taken from an orangish-violet anthropomorphous figure (clearer than sample G1).}

Figure 7 presents an image of sample G2, obtained by means of the stereoscopic microscope and magnified 45 times its original size. The pigment, between violet and orange in color, is found covering the surface of a whitish, at times translucent, rocky material.

The results of the element analysis of sample G2 (obtained through EDX) indicates a more complex composition than sample G1.

Figure 8 shows the TEM image corresponding to a pair of particles of the pigment in question, and Figure 9, the elementary spectra of two analyses performed on sample G2. The finding of elements such as silicon, calcium, etc. can once again be justified by their presence in the stone substrate and/or the filler material underlying the pigment. There is moreover the possibility that in this case the pigment (reddish gray-brown) includes more than one chemical compound. Thus, for example, the presence of copper has been detected, an element for which we have 


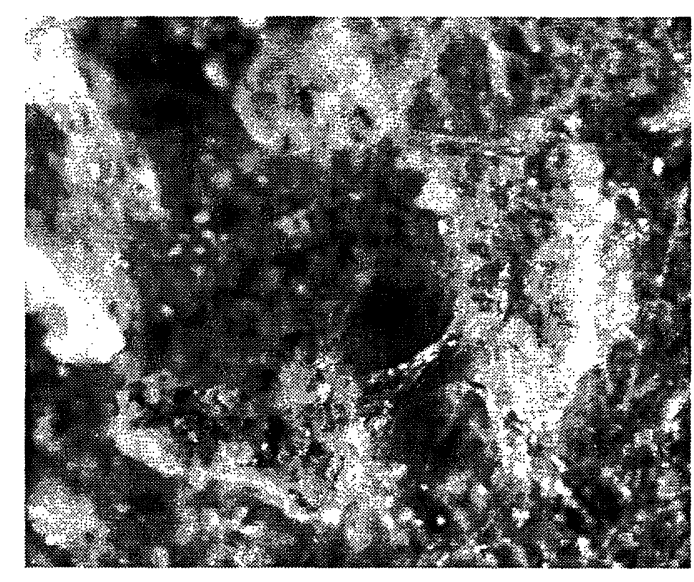

Figura 7.- Imagen de la muestra G2 (x45).

Figure 7.- Sample G2 (x45).

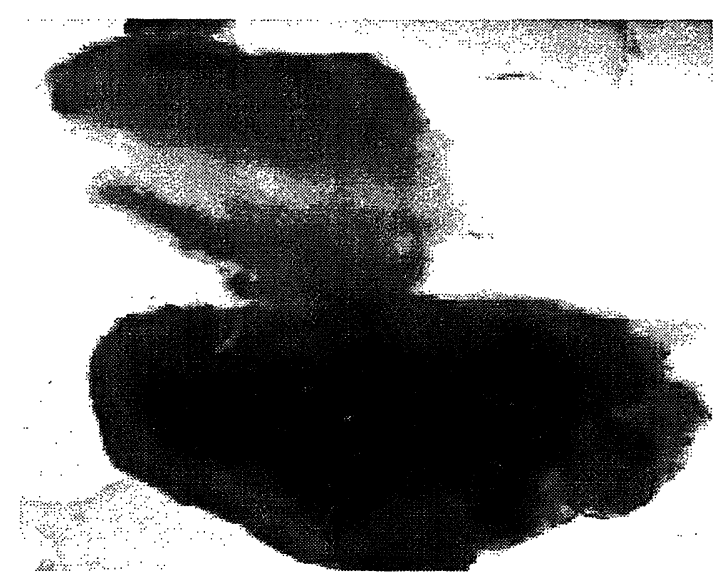

Figura 8.- Imagen TEM de la muestra G2.

Figure 8.- TEM image of sample G2.

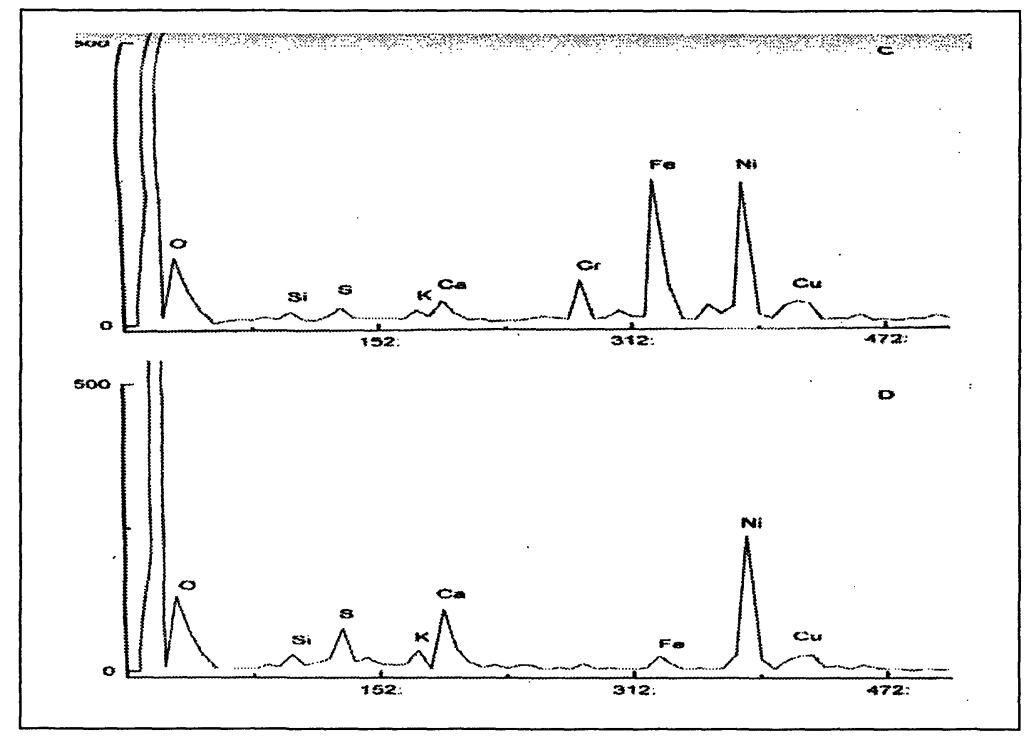

Figura 9.- Microanálisis de la muestra G2.

Figure 9.- Microanalysis of sample G2.

presencia de cobre, elemento sobre el que ya se han dado algunas explicaciones en torno a sus posibles combinaciones y las coloraciones que producen; se detecta también la presencia de hierro y la presencia de azufre (los principales minerales de hierro son precisamente óxidos y sulfuros tales como hematites $\left(\mathrm{Fe}_{2} \mathrm{O}_{3}\right)$, magnetita $\left(\mathrm{Fe}_{3} \mathrm{O}_{4}\right)$, limonita $\left(\mathrm{Fe}_{4} \mathrm{H}_{6} \mathrm{O}_{9}\right)$, pirita $\left(\mathrm{FeS}_{2}\right)$, etc.). Tanto el óxido férrico como el sulfuro de hierro poseen coloraciones pardo rojizas que pueden justificar perfectamente la coloración del pigmento de la muestra G2. Finalmente, hay que mencionar la presencia de pequeñas cantidades de elementos alcalinos ( $\mathrm{Na}$ y $\mathrm{K}$ ) y de cromo, metal éste que se suele encontrar en pequeña cantidad en muchos silicatos del tipo de la muscovita, la biotita, augita, etc. y, por consiguiente, en los productos de desintegración de las rocas que forman estos minerales. La detección de otros elementos tales como el níquel se justifica porque de níquel es la rejilla portamuestras que se introduce en la columna del microscopio. already provided some explanations regarding its possible combinations and the colorations that they produce. Both iron and sulfur were also found to be present (the main iron minerals are in fact oxides and sulfides, such as hematites $\left(\mathrm{Fe}_{2} \mathrm{O}_{3}\right)$, magnetite $\left(\mathrm{Fe}_{3} \mathrm{O}_{4}\right)$,

limonite $\left(\mathrm{Fe}_{4} \mathrm{H}_{6} \mathrm{O}_{9}\right)$, pyrite $\left(\mathrm{FeS}_{2}\right)$, etc.). Both ferric oxide and iron sulfide have reddish gray-brown colorations that could well account for the pigment hue of sample G2.

Finally, we must mention the presence of small amounts of alkaline elements ( $\mathrm{Na}$ and $\mathrm{K}$ ) and chromium, a metal that is usually found in small quantities in many silicates such as muscovite, biotite, augite, etc. and, consequently, in the disintegration products of rocks that form such minerals. As before, the detection of nickel can be considered an experimental artifact, as the sample-holder placed into the microscope column is made of this element. 
MUESTRA G3. Tomada de un trazo de color carmín en la parte superior de las pinturas

Llama la atención la intensa coloración que presenta la muestra G3. En la Figura 10 se puede observar una imagen, aumentada 105 veces, de las partículas extraídas a la pintura: el color carmín (rojo anaranjado) del pigmento sólo se ve levemente contaminado por la presencia de unas partículas blancas que bien podrían pertenecer al substrato pétreo donde se asienta la pintura o bien proceder del mismo material que el pigmento.

La marcada diferencia de color existente entre las representaciones gráficas de los distintos antropomorfos junto a la pureza cromática del pigmento G3 con el que, aparentemente, se llevó a cabo mas de un dibujo, sembraron unas dudas razonables en torno a la originalidad prehistórica de los dibujos de color rojo anaranjado.

Un espectro representativo de los análisis elementales realizados sobre la muestra G3 (por TEM/EDX) se da en la Figura 11. Asimismo, en la Figura 12 se presenta una imagen de alta resolución de una partícula del pigmento, en la que se pueden apreciar los planos interatómicos del material, y su correspondiente difracción de electrones.

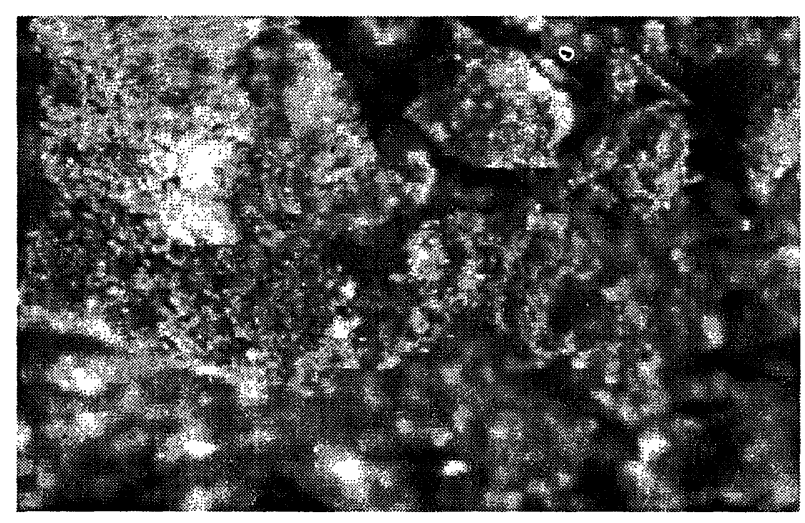

Figura 10.- Imagen de la muestra G3 (x 105).

Figure 10.- Sample G3 (x 105).

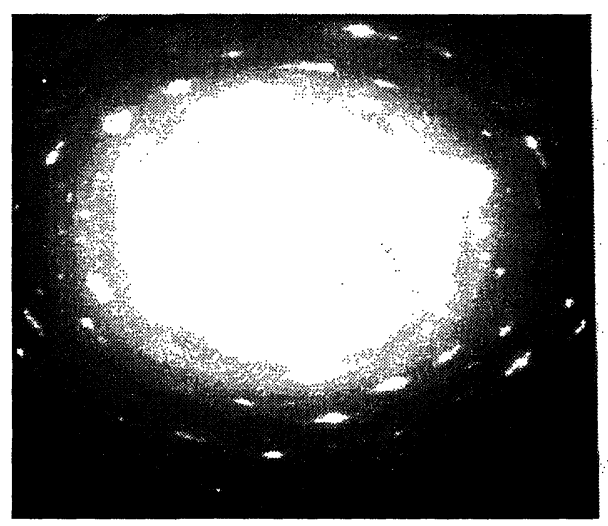

Figura 12.- Difracción de electrones e imagen de alta resolución de la muestra G3.

Figure 12.- Electron diffraction and high resolution image of sample G3.

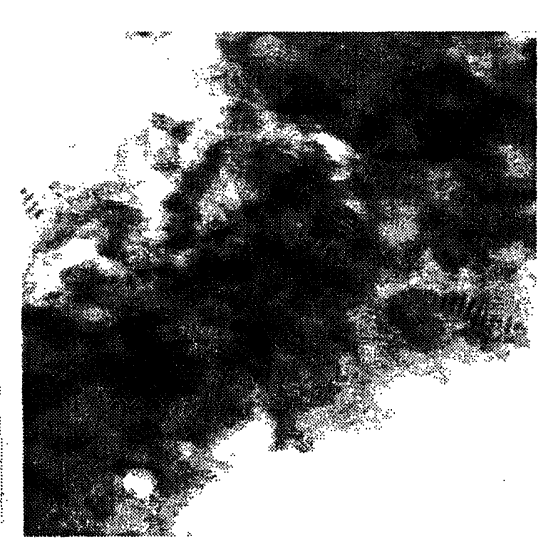

SAMPLE G3. Taken from a trace of vermilion color in the upper portion of the paintings

The intense coloration present in sample G3 attracts immediate attention. Figure 10 shows an image, enlarged 105 times, of the extracted paint particles: it is evident that the vermilion (red-orange) color is only slightly contaminated by the presence of some white particles that may as likely originate in the rocky substrate underlying the paint as in the pigment material itself.

The marked difference in color between the graphic representations of the different anthropomorphous figures, together with the chromatic brilliance of pigment $G 3$ (with which apparently more than one drawing was carried out) raises some reasonable doubts with regard to the prehistoric origins of the red-orange colored drawings.

A representative spectrum of the element analysis carried out on sample G3 (by TEM/EDX) is illustrated in Figure 11. Furthermore, Figure 12 presents a highresolution image of a pigment particle in which the material's interatomic plane can be appreciated, together with the corresponding electron diffraction.

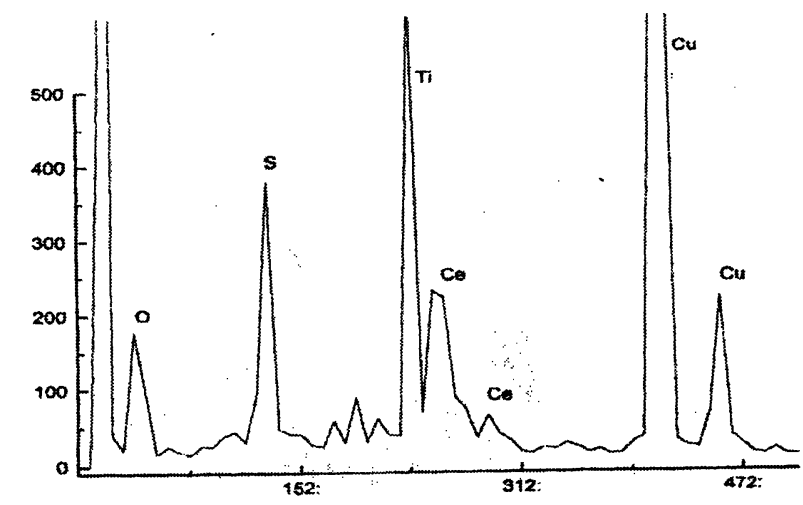

Figura 11.- Microanálisis de la muestra G3.

Figure 11.- Microanalysis of sample G3. 
La difracción de electrones indica, dada la brillante intensidad del espacio esférico junto a lo difuso de los halos que lo rodean y lo relativamente aleatorio en que se distribuyen las reflexiones, que el material muestreado posee una estructura pseudocristalina.

Sin duda alguna, el aspecto mas interesante de este pigmento procede de la interpretación de su microanálisis. Como elementos fundamentales que lo componen (ver Figura 11) se han identificado: el cobre, cuya presencia se debe a la rejilla del portamuestras (que en el caso del pigmento carmín era de este metal); el titanio, que habitualmente se presenta en la naturaleza en forma de óxido de titanio, bien como rutilo (tetragonal y de color pardo rojizo o pardo amarillento), bien como anatasa (tetragonal) o como brookita (rómbica), ambas de color blanco, lo que, en principio, hace suponer que sólo el primero de los minerales de titanio mencionados podría formar parte del pigmento cromóforo (la presencia de rutilo es coherente con los minerales existentes en la zona comprendida entre Despeñaperros y Andújar); y finalmente, se detectó en el espectro una serie consecutiva de 3 ó 4 líneas (alguna se encuentra solapada) cuya asignación fue difícil, primero porque la identificación automática del EDX generaba una lista de 4 ó 5 elementos posibles (todos ellos con alguna línea de energía en el rango objeto de estudio) y segundo porque la totalidad de dichos elementos se da en especies minerales muy escasas en la naturaleza (Tierras Raras). Tras un minucioso rastreo que implicó muchas pruebas y un análisis detallado de todos y cada uno de los elementos en cuestión, se concluyó que tan sólo tres podían ser el origen de las líneas que aparecían en el espectro: Cerio (L $\alpha$ en 4.84 $\mathrm{KeV}$ y $\mathrm{L} \beta$ en $5.61 \mathrm{KeV}$ ), Neodimio ( $\alpha \alpha$ en $5.23 \mathrm{KeV}$ y L $\beta$ en $6.09 \mathrm{KeV}$ ) y Europio ( $\mathrm{L} \alpha$ en $5.84 \mathrm{KeV}$ y $\mathrm{L} \beta$ en $6.84 \mathrm{KeV}$ ). Hay que tener en cuenta que todos estos elementos presentan sus principales líneas espectrales $(\mathrm{K} \alpha$ y $\mathrm{K} \beta$ ) en rangos energéticos superiores a los $34 \mathrm{KeV}$, siendo $20 \mathrm{KeV}$ el máximo capaz de detectar el equipo utilizado. Ello implicó una dificultad adicional de detección y asignación de señales.

El grupo de las «tierras raras» comprende 15 elementos (Escandio e Ytrio de la $3^{\text {a }}$ columna del sistema periódico y los elementos con número de orden 57 (Lantano) hasta 71 (Lutecio)). Aproximadamente, la mitad de las tierras escasas forman sales que tienen color. En la investigación espectroscópica se manifiesta el color de una manera especial: mientras que las bandas de absorción de otros cationes coloreados son, por lo general, anchas y difusas, las de las tierras escasas aparecen estrechas y bien limitadas pues los electrones absorbentes del color se encuentran sujetos débilmente aunque muy profundos en el interior del átomo. Esto explica que de unos elementos a otros puedan presentarse variaciones grandes de color mientras que sus propiedades químicas, que están fijadas por las capas electrónicas mas externas, invariables, permanecen prácticamente constantes.
Given the brilliant intensity of the spherical space, the electron diffraction, together with the spread of the surrounding halos and the relatively random way in which the reflections are distributed indicate that the sampled material possesses a pseudo-crystalline structure.

Without doubt, the most interesting aspect of this pigment lies in interpreting the results of microanalysis. The fundamental elements found to make it up (see Figure 11) include: copper, whose presence is due to the sampleholder; titanium, usually occurring in nature in the form of titanium oxide like Rutile (tetragonal and reddish or yellowish gray-brown in color), Anatase (tetragonal) or Brookite (rombic), both white in color, which in principle leads to the supposition that only the first of the abovementioned titanium minerals could be part of the chromophore pigment (in fact, the presence of rutile is consistent with the minerals existing in the area running from Despeñaperros to Andujar), finally, a consecutive series of 3 or 4 lines in the spectrum (some overlapping) was detected whose assignment was difficult, firstly, because the EDX automatic identification generated a list of 4 or 5 possible elements (all with some energy lines within the experimental range) and secondly, because all these elements occur in mineral species that are very scarce in nature (Rare Earths). After meticulous sifting that involved many tests and detailed analysis of each and every one of the elements in question, it was concluded that there could be only three possible origins for the lines appearing in the spectrum: Cerium ( $L \alpha$ in $4.84 \mathrm{KeV}$ and $L \beta$ in $5.61 \mathrm{KeV}$ ), Neodymium ( $L \alpha$ in $5.23 \mathrm{KeV}$ and $L \beta$ in $6.09 \mathrm{KeV}$ ) and Europium ( $L \alpha$ in $5.84 \mathrm{KeV}$ and $L \beta$ in 6.84 $\mathrm{KeV}$ ). It should be borne in mind that all these elements present their main spectral lines $(K \alpha$ and $K \beta)$ in energy ranges above $34 \mathrm{KeV}$, and that $20 \mathrm{KeV}$ is the maximum value which the equipment used can detect. This engendered additional difficulty in detection and the assignment of signs.

The group of the "rare earths» includes 15 elements (Scandium and Yttrium in the $3^{\text {th }}$ column of the periodic table and the elements with atomic number 57 (Lanthanum) up to 71 (Lutetium)). Approximately half of the rare earths form colored salts. In spectroscopic analysis their colors are displayed in a peculiar fashion: while the absorption bands of other colored cations are generally wide and diffuse, those of the rare earths appear narrow and well-delimited, as the color-absorbing electrons are bound weakly, though quite deep within the atom's interior. This explains why large variations in color are found from one element to the next, while their chemical properties, which are determined by the invariable, outer-most electron layers, remain practically the same. 
El caso concreto del pigmento G3, como se indicó anteriormente, implicó una revisión de la mineralogía correspondiente a los tres elementos posibles $(\mathrm{Ce}, \mathrm{Nd}$ y $\mathrm{Eu}$ ) identificados por TEM/EDX. Las conclusiones extraídas fueron las siguientes: El Cerio forma dos óxidos $\mathrm{Ce}_{2} \mathrm{O}_{3}$ y $\mathrm{CeO}_{2}$ que son anhidridos de bases y que dan lugar a sales; las sales cerosas que derivan del $\mathrm{Ce}_{2} \mathrm{O}_{3}$ son incoloras y las céricas, que derivan del $\mathrm{CeO}_{2}$, son de color rojo anaranjado ( Es característico de todas las sales céricas el hermoso color anaranjado que tienen y además su gran tendencia a formar sales básicas difícilmente solubles» escribe F.P. Treadwell (1) en su tratado de química analítica). El Neodimio, por su parte, es, después del Cerio y el Lantano, la tierra rara más importante en las arenas monacíticas y en la cerita. Las sales de Neodimio son de color rosa violeta y con luz reflejada presentan fluorescencia azulada. Finalmente, el Europio es algo más desconocido que los anteriores elementos. Se sabe, en cualquier caso, de su gran capacidad de magnetización y de la existencia de alguna sal de Europio de color blanco.

Parece muy probable, pues, que la coloración del pigmento sea debida a una sal cérica, aunque no se debería descartar la aportación de color de los otros elementos, especialmente del titanio en forma de rutilo.

MUESTRA G4. Tomada en la parte inferior de la pared con pinturas, zona de abundante presencia de «grafiti».

Observada a la lupa, la muestra G4 presenta la apariencia de un substrato rocoso sobre el que se encuentra depositado una minúscula cantidad de partículas de color pardo anaranjado (ver Figura 13).

El microanálisis de dicha muestra (ver Figura 14) revela la presencia de una serie de elementos químicos en torno a los cuales no resulta difícil trazar una hipótesis del color de este pigmento. El hierro, fundamentalmente, aunque en

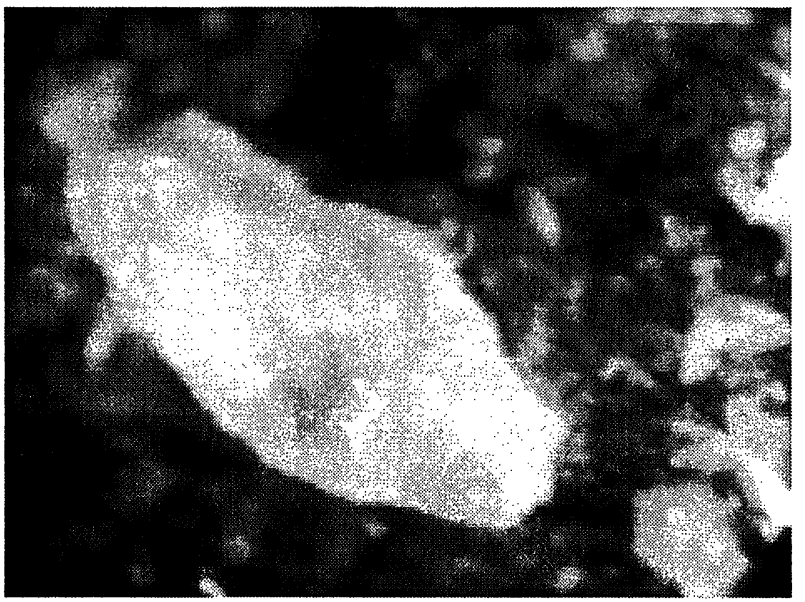

Figura 13.- Imagen de la muestra G4 (x50).

Figure 13.- Sample G4 (x50).
As indicated in the foregoing, the specific case of pigment $G 3$ involved a review of the mineralogy corresponding to the three possible elements identified by TEM/EDX (Ce, $\mathrm{Nd}$ and $\mathrm{Eu}$ ). The conclusions drawn are the following: the Cerium forms two oxides $\mathrm{Ce}_{2} \mathrm{O}_{3}$ and $\mathrm{CeO}_{2}$, which are basic anhydrides that give rise to salts; the cerous salts that stem from $\mathrm{Ce}_{2} \mathrm{O}_{3}$ are colorless and the ceric ones, deriving from $\mathrm{CeO}_{2}$, are orange-red in color ( «the beautiful orange color is characteristic of all the ceric salts, which also have a great tendency to form quite insoluble basic salts» writes F.P. Treadwell (1) in his analytical chemistry text). Neodymium, on the other hand, is apart from Cerium and Lanthanum, the most important rare earth in monacytic sands and cerite. Neodymium salts are pink-violet in color and exhibit blue fluorescence to reflected light. Finally, Europium is rather less wellknown than the previous element, though two well known facts are its great capacity for magnetization and the existence of some Europium salts that are white in color.

It therefore seems very likely that the color of this pigment is due to a ceric salt, as well as titanium present in the form of rutile.

SAMPLE G4. Taken from the lower portion of the wall bearing paintings, an area of abundant «graffiti».

Observed with a magnifying lens, sample G4 appears to be made up of a rocky substrate on which a minuscule amount of orangish gray-brown particles is deposited (see Figure 13).

Microanalysis of this sample (see Figure 14) reveals the presence of a series of chemical elements from which it is not difficult to formulate a hypothesis regarding the

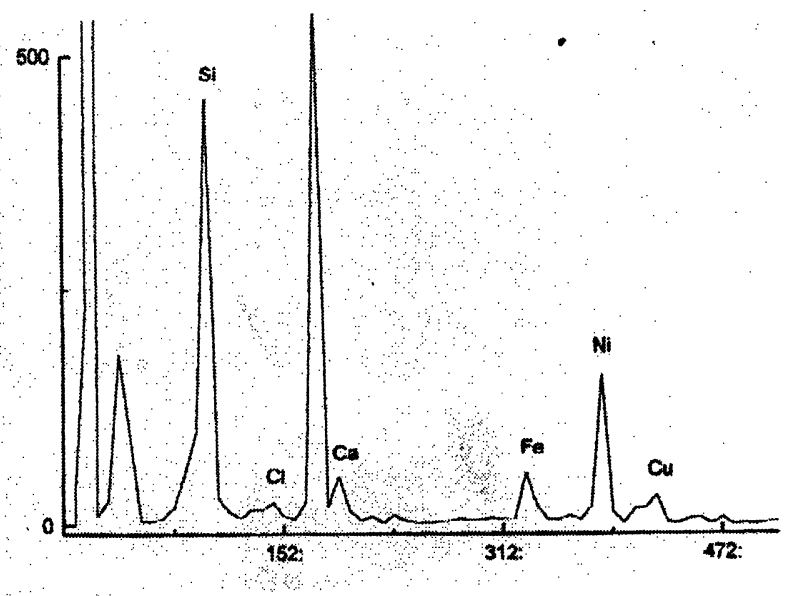

Figura 14.- Microanálisis de la muestra G4.

Figure 14.- Microanaly'sis of sample G4. 
pequeña proporción (de ahí la poca intensidad de color de la pintura), y el cobre, en cantidades de trazas (prácticamente se encuentra en los límites de detección), constituyen los únicos elementos cromóforos identificados en la muestra G4. Elevados contenidos de Aluminio, Silicio y Potasio parecen indicar la presencia en el substrato pétreo, de silicatos del tipo Ortoclasa, Adularia, Moscovita, etc. Adicionalmente, la presencia de illitas en el substrato pétreo complementaría los argumentos que justifican un contenido tan abundante de este elemento. Por último, unas cantidades de potasio elevadas, como las detectadas en la muestra G4 podrían también tener, al menos parcialmente, cierto origen orgánico, consecuencia de la actividad biológica desarrollada en la cueva, dado que dicho elemento es parte integrante y esencial del protoplasma.

\section{DIGITALIZACIÓN DE IMÁGENES Y ANÁLISIS DE CONTORNOS Y SUPERFICIES}

Simultáneamente a la toma de muestras, se llevó a cabo un reportaje fotográfico de las pinturas. De la digitalización de algunas imágenes seleccionadas de entre todas las fotografiadas y del análisis estadístico de dichas imágenes se pensó que se podría obtener información en torno al grado de deterioro de las pinturas estudiadas.

La utilización de sistemas computacionales ha hecho que la fotografía clásica se convirtiera en un medio de transferir determinada información que, por si sola, no podría ser detectada y, consecuentemente, interpretada. Una imagen es, en definitiva, un objeto plano cuyo brillo o color puede variar de un punto a otro.

Matemáticamente, la imagen se puede representar como una función $\mathbf{f}(\mathbf{x}, \mathbf{y})$, positiva y finita, en donde $\mathbf{x}$ e $\mathbf{y}$ son las coordenadas espaciales y el valor de $\mathbf{f}$ es proporcional al brillo de la imagen en ese punto. $\mathrm{Al}$ valor $\mathbf{f}$ en $(\mathbf{x}, \mathbf{y})$ se le denomina «nivel de gris» en la imagen. Esta función se puede discretizar, tanto en coordenadas espaciales como en niveles de gris. A esta operación se le denomina digitalización y da lugar a una matriz de datos numéricos $(\mathbf{P})$, compuesta por $\mathbf{x}$ filas e $\mathbf{y}$ columnas, donde a cada elemento de la misma $\mathbf{P}(\mathbf{x}, \mathbf{y})$ se le asocia una intensidad $\mathbf{z}$ o nivel de gris en ese punto. Cada elemento o punto de la matriz es denominado «pixel» y tendría un equivalente fácilmente comprensible en el concepto de tesela en que se basan los mosaicos (2).

El tratamiento digital se podría definir como el proceso al que se somete una imagen (una fotografia, por ejemplo) para obtener otra, modificada, que conserve ciertas características de la original pero que genere una información adicional que pueda ser interpretada por el ordenador. coloration of this pigment. For the most part it is iron, albeit in small proportions (whence the paint's low color intensity), and copper in trace amounts (practically at the limits of detection) that constitute the only chromophore elements identified in sample G4. High concentrations of Aluminum, Silicon and Potassium seem to indicate the presence in the rocky substratum of silicates similar to Ortoclase, Adularia, Muscovite, etc. In addition, the presence of illites in the rocky substrate support the arguments for this as the origin of such an abundance of this compound in the sample. Lastly, rather high quantities of potassium, like those detected in sample G4 may also have, at least partially, organic origins consequent to biological activity carried out in the cave, since this element is an integral and essential part of cellular protoplasm.

\section{IMAGE DIGITALIZATION AND ANALYSIS OF CONTOURS AND SURFACES}

At the same time samples were collected, a photographic survey of the paintings was carried out as well. It was thought that by digitizing some images selected from amongst all the photos and statistically analyzing them, we could obtain information about the degree of deterioration of the paintings under study.

The use of computer systems has transformed the traditional photograph into a means of transferring specific information that can be detected and consequently interpreted in a manner which a photograph alone could not provide for. An image is actually a plane object whose luminance or color varies from one point to the next. Mathematically, an image can be represented as a positive finite function $f(x, y)$, where $\boldsymbol{x}$ and $\boldsymbol{y}$ and are the coordinates in space, and the value of $f$ is proportional to the luminance of the image at that point. The value off in $(x, y)$ is termed the "gray scale» of the image. This function can be discretized, both in its spatial coordinates, as well as its gray scales. This operation is termed digitization and gives rise to a numerical data matrix $(\boldsymbol{P})$, made up of $\boldsymbol{x}$ rows and $\boldsymbol{y}$ columns, which assigns to each element of $\boldsymbol{P}(\boldsymbol{x}, \boldsymbol{y})$ an intensity $z$ or gray scale at that point. Each element or point of the matrix is denominated a "pixel". An easily understandable analogy would be the concept of the tessellations on which mosaics are based (2).

Digital image processing can be defined as the mathematical operations to which an image (a photo, for example) is subjected in order to obtain another, modified one, that conserves certain characteristics of the original, but which however contains additional information that can be interpreted by means of the computer. 
En el caso concreto de las pinturas rupestres localizadas en la cueva de «La Graja» se ha seguido un procedimiento de análisis de imágenes tal y como se expone a continuación, con el fin fundamental de aportar algún dato en torno al estado de conservación de dichas pinturas. Tres fueron los símbolos seleccionados para su estudio por esta técnica:

\section{ANTROPOMORFO DE COLOR CARMESÍ}

Dado lo excepcional del análisis del pigmento cromóforo que conforma este símbolo, se decidió hacer un tratamiento digital de una representación de color rojo por si de dicho estudio pudiera extraerse información adicional.

En la Figura 15 se puede observar el proceso seguido para extraer la información posible de la imagen seleccionada, que, en este caso, procede de la Figura 2.
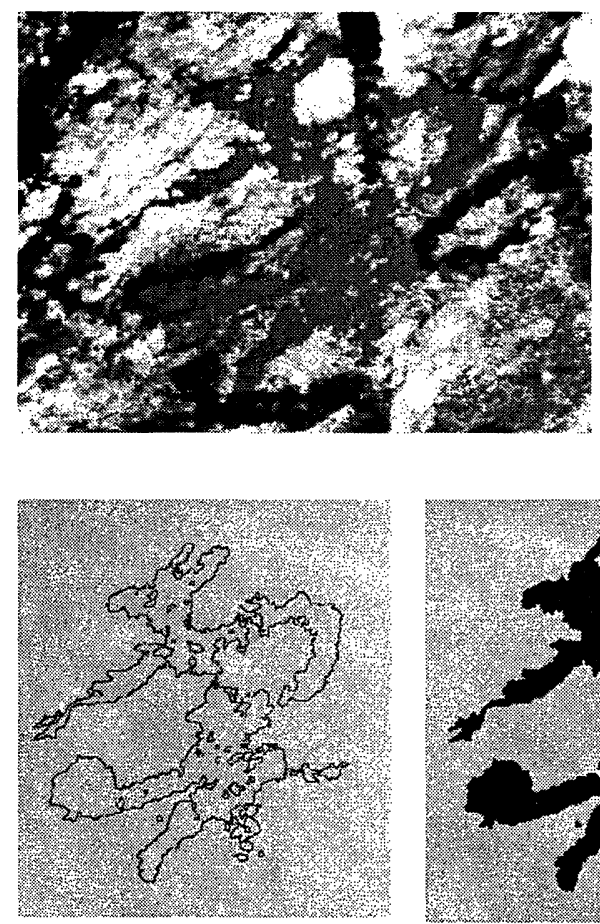

Etapa c/Step c

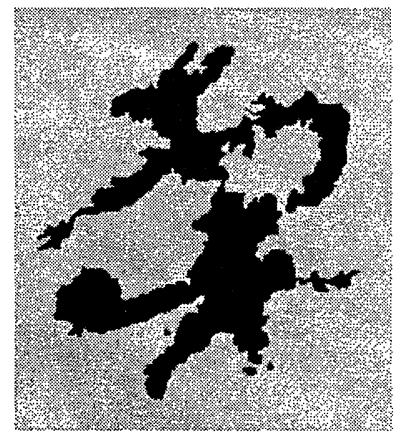

Etapa d/Step d

In the specific case of the rupestral paintings located in the cave of "La Graja», a procedure was followed for analyzing the images (as outlined in the following) with the basic aim of uncovering any information regarding the state of conservation of these paintings. Three figures were selected for study by this technique:

\section{VERMILION-COLORED ANTHROPOMORPHOUS IMAGES}

Given the exceptional nature of the chromophore pigment analysis relative to this figure, it was decided to digitally proces's a red-colored representation in the hope that such study might provide us with further useful information.

Figure 15 illustrates the process adopted in order to gather any possible data on the selected image, which in this case is that shown in Figure 2.

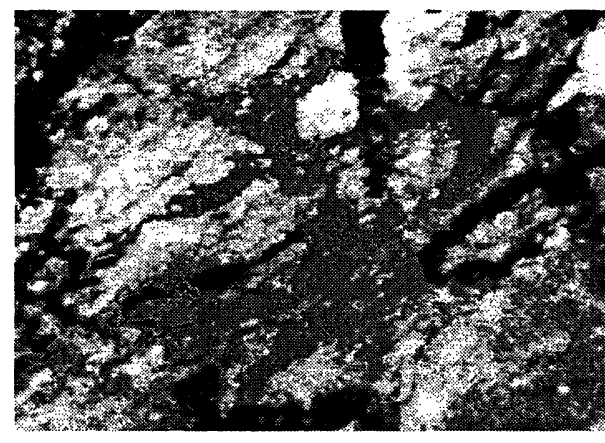

Etapa b/Step b

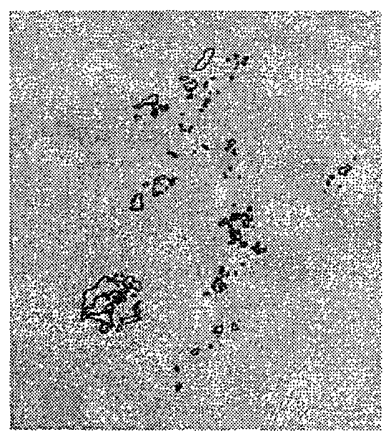

Etapa e/Step e

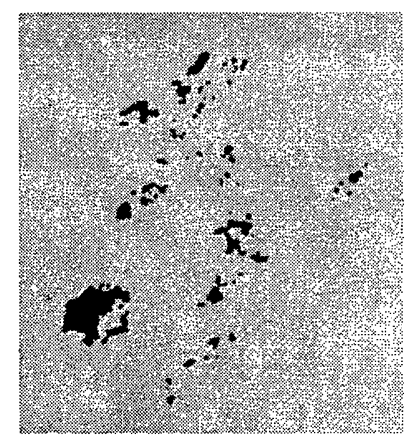

Etapa f/Step $f$

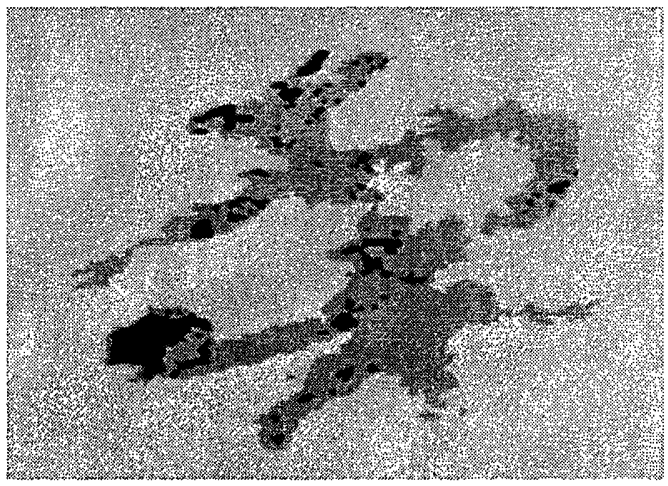

Etapa g/Step g

Figura 15.- Proceso seguido en el tratamiento de las imágenes.

Figure 15.- Image digitatalization process. 
El primer paso consistió en transformar la imagen (fotografía, en este caso) en una señal capaz de ser leída e interpretada por el ordenador. Este fue el momento de definir el tamaño de la matriz a emplear

Inmediatamente después se procedió a la mejora (restauración) de la señal captada al objeto de evitar, o en su caso minimizar, las imperfecciones de la señal, producidas por la pérdida de definición y fidelidad de la imagen tanto en el momento de su captura como en el de transformación a la señal digital.

La restauración se llevó a cabo mediante la aplicación de una serie de algoritmos cuyos objetivos consisten en la modificación de los niveles de gris, la transformación del contraste, la reducción del ruido, el realce de bordes, interpolaciones, pseudocoloraciones, etc. Es importante señalar que una operación de mejora no añade información nueva sino que aumenta el rango dinámico de las características buscadas de forma que en las posteriores etapas del tratamiento de imágenes, sean mas fácilmente localizables y modificables.

La Figura 15a corresponde a la región objeto de estudio, una vez ampliada y mejorada en lo que a su contraste respecta, y la Figura 15b es la misma imagen anterior, una vez perfilada o ecualizada (se puede observar en dicha imagen una definición de contornos donde cabe resaltar una serie de «islotes» de color negro, en el interior de la figura del antropomorfo rojo, que en la fotografía original coinciden con unas pigmentaciones diferentes a la carmesí o con unas alteraciones de ésta).

A partir de la imagen resultante del primer proceso de restauración se desglosó y clasificó la información tratada para extraer finalmente las conclusiones deseadas. En definitiva, el proceso, denominado de «segmentación» genera una imagen, tras un reconocimiento de áreas, texturas, formas, etc., con las propiedades o zonas de interés buscadas (el procedimiento consiste en acotar un rango de valores de gris que previamente se han definido, y reasignar aquél a un valor de salida 1 y el resto a 0 ; el resultado es una imagen binaria. La segmentación puede hacerse estableciendo varios rangos y reasignándoles a cada uno de ellos un nivel de gris determinado; el resultado final es la imagen clasificada).

La Figura 15c es una imagen total de bordes del antropomorfo y la Figura 15d es, esa misma imagen, «segmentada».

Las Figuras $15 \mathrm{e}$ y $15 \mathrm{f}$ corresponden, respectivamente, a la imagen de bordes de la zona del antropomorfo que se podría calificar de alterada, y a su imagen segmentada o de relleno.
The first step consisted of transforming the image (a photo in this case) into signals that can be read and interpreted by computer. It is at this stage that the matrix size to be used must be decided upon.

Immediately thereafter we proceeded to enhancing (restoring) the digitized signals with the aim of avoiding, or at least minimizing, the imperfections consequent to the loss of image definition and fidelity during both the photographic stage as well as the transformation into digital signals.

Restoration was carried out by applying a series of algorithms for modifying the gray scales, adjusting contrast, reducing noise, enhancing borders, interpolating and pseudo-colorizing, etc. It should be pointed out that such enhancement operations add no new information to the image, but rather increase the dynamic range of the desired characteristics so that in the later stages of the image processing, they can be more easily located and modified.

Figure 15a corresponds to the region of interest after magnification and contrast enhancement, and Figure $15 b$ presents this same image after retouching, or equalization - the well-defined contours are evident in the figure (especially noteworthy is the series of black-colored "islets» within the interior of the red anthropomorphous figure, which in the original photograph correspond to several pigmentations that are either different from, or some modification of the vermilion pigment).

Beginning with the image resulting from the first restoration procedure, we subdivided and classified the information obtained in order to finally arrive at the desired conclusions. In short, this process, denominated "segmentation", generates an image by recognizing certain areas, textures, forms, etc., with the desired properties or zones of interest (the procedure consists of delimiting a range of previously defined gray values, and reassigning to this range an output value of 1 , and setting the rest to 0 , the result being a binary image.

Segmentation can be performed by establishing several ranges and reassigning a certain gray scale to each one of them; the final result is the "classified" image).

Figure 15c shows an integral image of the borders of the anthropomorphous drawing, while figure $15 d$ presents the same image, only this time, "ssegmented».

Figures 15 and $15 f$ correspond to images of a border area of the anthropomorphous figure, which may be categorized as altered, and its segmented image, respectively, 
Finalmente, la Figura $15 \mathrm{~g}$ es una imagen «clasificada» del antropomorfo rojo en la que se observa con tonalidad azul celeste la superficie coloreada con el pigmento carmín y con tonalidad azul oscura la parte alterada.

Del estudio de la secuencia de imágenes descritas, no se puede concluir nada en torno a la originalidad histórica de este elemento concreto pero si se pueden hacer algunas consideraciones tales como que la pintura de este símbolo parece, en términos generales, bastante bien conservada; mantiene una importante uniformidad en el interior de los contornos que configuran el citado símbolo que mejora la media de las pinturas existentes. La razón de esta aceptable conservación podría buscarse en el tiempo (está dentro de lo posible que este antropomorfo no sea tan antiguo como los otros símbolos) y también en el altísimo grado de insolubilidad del pigmento que lo conforma.

\section{PAREJAANTROPOMÓRFICA}

Ligeramente alejados del espacio pictórico en el que se concentra el mayor número de símbolos rupestres, se observa una pareja antropomórfica de similar coloración entre sí sobre los que se decidió realizar un tratamiento digital de imágenes. El resultado de dicho tratamiento, paralelamente ejecutado con ambos símbolos, es prácticamente idéntico en las dos figuras por lo que, a continuación, se muestra exclusivamente la secuencia de imágenes del símbolo mayor:

Figura 16a. Imagen restaurada a partir de la fotografía que se muestra en la Figura 3. Dicha fotografía fue digitalizada y las regiones de interés fueron ampliadas. Las imágenes a estudiar fueron mejoradas en sus aspectos de contraste y brillo.

Figura 16b. Imagen ecualizada en las que se puede observar con nitidez la definición de los contornos del símbolo. Igualmente se pueden distinguir zonas en las que presumiblemente ha desaparecido el pigmento cromóforo y zonas que muestran una ligera falta de uniformidad en el tono de las pinturas.

Figura 16c. Imagen de bordes en la que se trata de enfatizar, no sólo la perfecta definición de los contornos sino su grado de alteración, puesto de manifiesto a través de las diferencias cromáticas que constituyen dicha figura.

Figura 16d. Imagen clasificada y cuantificada en la que se puede identificar la superficie de color oscuro con la superficie pictórica original o menos alterada
Finally, figure $15 \mathrm{~g}$ is a "classified》 image of the red anthropomorphous figure in which the surface colored with the vermilion pigment appears celestial blue hue and the altered portion as dark blue.

The foregoing study of the image sequence per se does not allow conclusions to be drawn regarding the historical origins of this specific element. However, we may advance some considerations, such as, the paint in this symbol seems, in general terms, quite well conserved: considerable uniformity has been maintained within the contours delimiting it, which improves the average of the existing paint. The reason for this good state of conservation may well lie in the short time of its existence (it is possible that this anthropomorphous representation is not as old as the other figures), or also in the high degree of insolubility of its component pigment.

\section{ANTHROPOMORPHIC PAIR}

A pair of anthropomorphic figures, both with similar coloration, is found slightly removed from the area in which most of the rupestral symbols are concentrated. It was decided to perform digital processing of these images, executed in parallel on both. As the results are practically identical for the two figures, the image sequence illustrated in the following refers exclusively to the larger of the two:

Figure 16a. Restored image of the sampled picture presented in Figure 3. The photograph was digitized and the regions of interest were enlarged. The images to be studied were enhanced for contrast and luminance.

Figure 16b. Equalized image in which the high definition of the symbol's contours are clearly visible. Moreover, areas can be distinguished where the chromophore pigment has presumably disappeared, while in others the paint's hue reveals a slight lack of uniformity.

Figure 16c. Border image which attempts to highlight not only the perfect definition of the contours, but its degree of alteration, revealed by the chromatic variations making up the figure.

Figure 16d. Classified and quantified image in which the dark-colored surface represents the original, or at least less altered pictorial surface, while the orange-colored 
y la superficie color anaranjado con la superficie del símbolo, que, manteniendo visible su pigmentación, ésta ha perdido intensidad en el color como consecuencia naturalmente del paso del tiempo. Las zonas más alteradas se representan en color amarillo. Las zonas donde se ha perdido definitivamente la pintura, aunque resultan obvias (en la Figura 16a se observa esto muy bien), no se pueden cuantificar, a menos que se hiciera una reconstrucción del símbolo original.

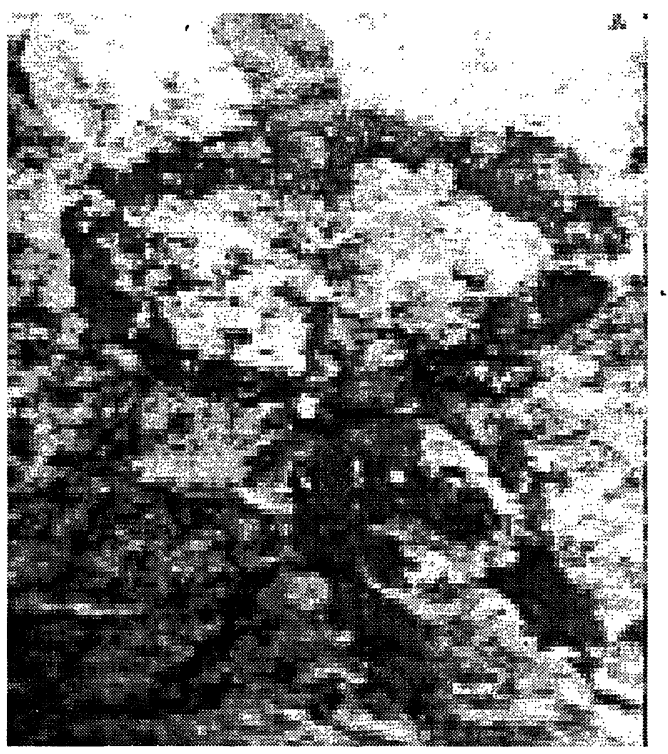

Etapa a/Step a

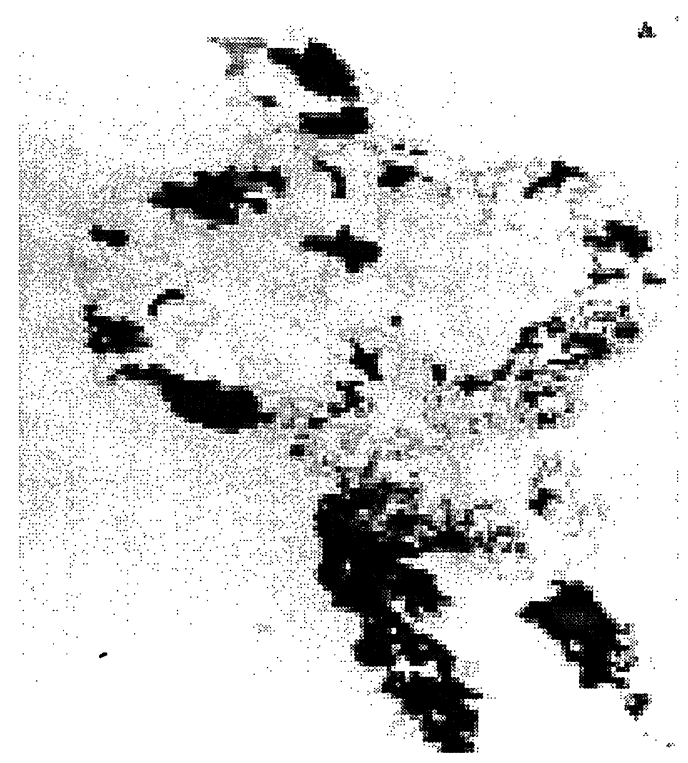

Etapa c/Step c surface coincides with that of the symbol whose pigmentation, though remaining visible, has lost color intensity as a natural consequence of the passage of time. The most highly altered zones are depicted in yellow. Although the areas where it has definitively lost its paint are obvious (as Figure 16a clearly shows), they could not be quantified without fully reconstructing the original symbol.

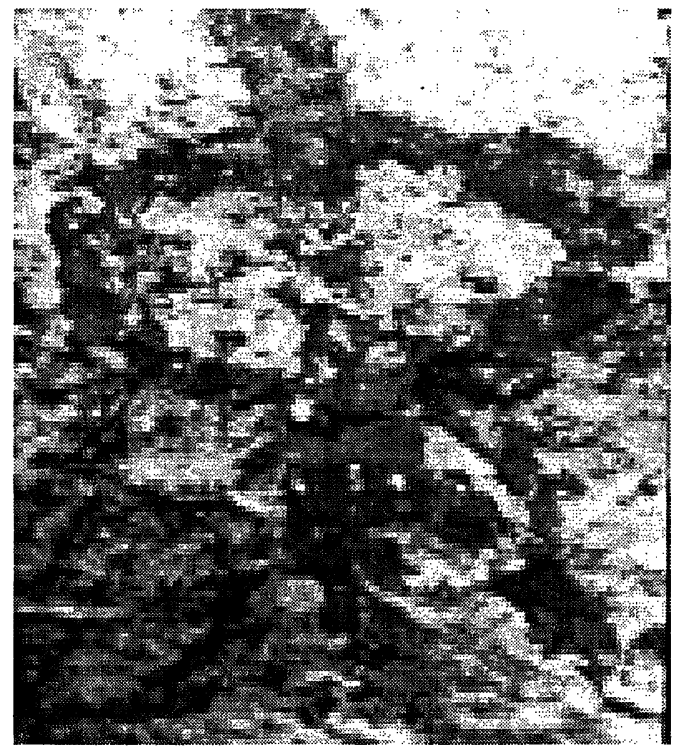

Etapa b/Step b

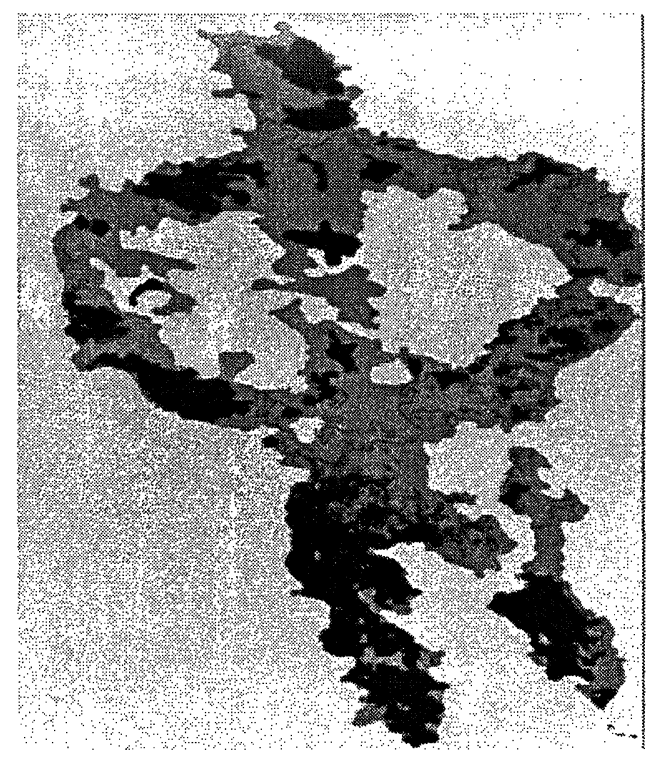

Etapa d/Step d

Figura 16.- Etapas seguidas en el tratamiento digital de las imágenes

Figure 16.- Steps of the image digitalization process 


\section{CONCLUSIONES}

Los procesos naturales de alteración observados en la cueva de «La Graja» están relacionados, fundamentalmente, con la alta disponibilidad de agua en su zona de ubicación. Las medidas correctoras que podrían tomarse consistirían en canaliząr el agua en la parte superior del abrigo y, de esa forma, impedir su circulación por el panel de pinturas, aunque, en este caso, la efectividad de dicha medida podría verse atenuada por la percolación de aguas calcificantes que se produce en el interior de las fisuras de la roca encajante.

La composición química de los pigmentos que conforman las pinturas rupestres varian substancialmente de las encontradas en otros estudios semejantes llevados a cabo en la región de Andalucía y en los que predomina la presencia del hierro. En este sentido, destaca la presencia de óxidos de cobre en uno de los antropomorfos de la cueva y la presencia de titanio y tierras raras (sales de cerio) en unos trazos de color carmín que forman parte del conjunto de pinturas. Todo ello sugiere la necesidad de extender la investigación a otros antropomorfos, representaciones animales, trazos puntiformes, etc., de la cueva, al objeto de formular hipótesis coherentes en torno al origen de estos elementos en los pigmentos utilizados para la realización de las pinturas.

El análisis de imágenes llevado a cabo indica que las pinturas estudiadas están bien conservadas, con uniformidad del pigmento en el interior de los bordes.

\section{AGRADECIMIENTOS}

Los autores desean expresar su agradecimiento a la Consejería de Cultura de la Junta de Andalucía por la financiación de los trabajos que han dado lugar a la presente publicación. Igualmente a los Dres. Hoyos (MNCN), Saiz (IRNA) y Puertas (IETcc) por sus enriquecedoras aportaciones.

\section{CONCLUSIONS}

The natural alteration processes observed in the cave of «La Graja» are related essentially to the high availability of water in the zone of its location. The possible corrective measures to be taken would consist of channeling the water away from the shelter's upper portion and in this way impede its flow over the painted panel, although in this case the effectiveness of such measures may be attenuated by the percolation of calcifying waters that takes place within the cracks of the surrounding rock.

The chemical composition of the pigments making up the rupestral paintings diverges substantially from those found in other similar studies carried out in the region of Andalucia, in which iron has been found to prevail. In this regard, exceptional findings include the presence of copper oxides in one of the cave's anthropomorphous figures, as well as the presence of titanium and rare earths (cerium salts) in some vermilion-colored traces encountered in the group of paintings. Overall, the present findings indicate the need to extend the investigation to other anthropomorphous and animal representations, point traces and the like within the cave, with the aim of formulating a consistent hypothesis regarding the origin of these elements in the pigments used to create the paintings.

The analyses performed on the images indicate that the studied paintings are well conserved, with uniform pigment distribution within the borders' interior.

\section{ACKNOWLEDGEMENTS}

The authors wish to express their gratitude to the Consejeria de Cultura de la Junta de Andalucia (Culture Council of the Andalusian Regional Government) for the funding of the work that has given rise to this publication. Our most heartfelt appreciation also goes to Drs. Hoyos (MNCN), Saiz (IRNA) and Puertas (IETcc) for their invaluable contributions.

\section{BIBLIOGRAFÍA}

(1) Treadwell, W.D. «Tratado de Química Analítica» Ed. Marín. Barcelona (Spain) 1950

(2) González R. C. and Woods R.E. «Digital Image Processing» Ed. Addison-Wesley Publ. Co. Inc. USA 1992. 


\title{
Publicación del Instituto Eduardo Torroja-CSIC
}

Razón y Ser de los tipos estructurales alcanza en la Colección "Textos Universitarios" su séptima edición. Las anteriores fueron publicadas sucesivamente por el Consejo Superior de
Investigaciones

Cientificas a través del Instituto de Ciencias de la Construcción "Eduardo Torroja", que lleva el nombre de su autor. El prestigio internacional de Eduardo Torroja Miret

\section{TEXTOS UNIVERSITARIOS}

\author{
EDUARDO TORROJA MIRET
}

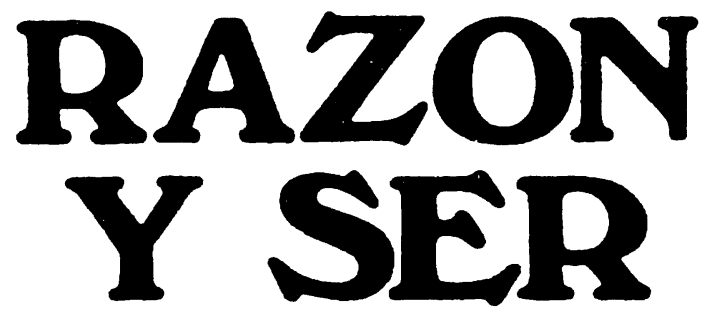

DE LOS TIPOS ESTRUCTURALES

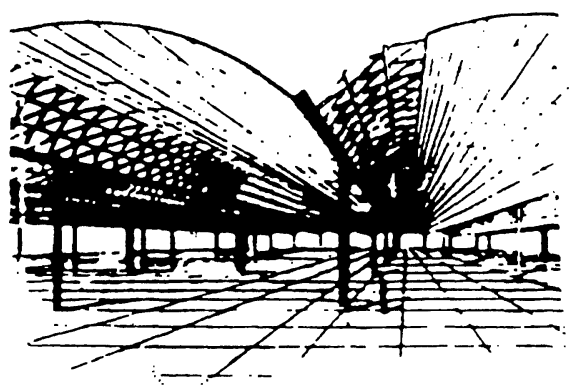

Consejo Superior de Investigaciones Cientificas

dentro de la Ingenieria como creador e innovador en el campo de las estructuras, es bien conocido. Esta capacidad excepcional de creación, interpretación $e$ innovación queda perfectamente reflejada en este libro.

Obra fundamental de notable contenido formativo y didáctico para los estudiantes $y$ estudiosos de la Arquitectura y la Ingenieria, Razón y Ser mantiene, a pesar del tiempo transcurrido desde su edición original, plena vigencia.

Este hecho y la demanda continua de ejemplares, dentro y fuera de España, nos ha animado a su reedición en una colección que como "Textos Universitarios" se plantea llevar a sus lectores obras fundamentales de permanente demanda, $y$ nuevas aportaciones igualmente importantes tanto por la novedad de sus contenidos, como por la solidez y actualidad de los miśmos.

Finalmente, esta nueva edición de Razón y Ser mejora, a nuestro juicio, la calidad.editorial y presentación de las anteriores, y esperamos obtenga la misma acogida de las que la precedieron.

Madrid, octubre 1991 